\title{
PENGARUH KONSUMSI REBUSAN JANTUNG PISANG TERHADAP EKSKRESI ASI PADA IBU MENYUSUI DI DESA RANAH WILAYAH KERJA PUSKESMAS KAMPAR TAHUN 2016
}

\author{
Riani \\ Dosen FIK Universitas Pahlawan Tuanku Tambusai, Riau, Indonesia
}

\begin{abstract}
ABSTRAK
Cakupan pemberian ASI Eksklusif di Indonesia tahun 2013hanya $42 \%$ angka ini masih dibawah target WHO 50\%. Penyebabnya adalah biasanya ASI sulit keluar pada hari pertama menyusui, ASI yang tidak cukup karena sulit keluar, bayi jadi malas menghisap sehingga terjadi proses pembendungan pada payudara. Diperlukan ramuan untuk membantu memperlancar kembali pengeluaran ASI yaitu dengan mengkonsumsi rebusan jantung pisang. Tujuan penelitian ini adalah pengaruh konsumsi rebusan jantung terhadap ekskresi ASI pada ibu menyusui di Desa Ranah wilayah kerja Puskesmas Kampar tahun 2016. Metode penelitianquasi eksperimen (eksperimen semu) dengan rancangan non-equivalent pretest-posttest. Populasi dalam penelitian ini adalah seluruh Ibu Menyusui < 40 hari sebanyak 20orang. Adapun tehnik pengambilan sampel menggunakan tehnik purposive sampling. Analisa data univariat dan bivariate yang diuji dengan Paired T-test. Hasil penelitian diperoleh bahwa rerata ekskresi ASI sebelum konsumsi rebusan jantung pisang adalah $385 \mathrm{cc}$ dengan standar deviasi 82,876 dan sesudah konsumsi rebusan jantung pisang adalah 720,00 cc dengan standar deviasi 86,450 . Hasil uji statistik didapatkan nilai p value 0,001 , maka dapat disimpulkan ada pengaruh konsumsi rebusan jantung pisang terhadap ekskresi ASI pada ibu menyusui di Desa Ranah wilayah kerja Puskesmas Kampar tahun 2016.Diharapkan kepada Ibu-Ibu didesa tersebut untuk aktif berkonsultasi kebidan desa terlebih dahulu perihal kendalakendala menyusui sebelum memutuskan memberikan susu formula, sehingga pemberian ASI eksklusif ini dapat terlaksana dengan baik.
\end{abstract}

Daftar Bacaan :20 ( 2008 - 2015)

Kata Kunci :Jantung Pisang, Ekskresi ASI

\section{BAB I PENDAHULUAN}

\section{A. Latar Belakang}

ASI merupakan makanan pertama bagi bayi yang nutrisinya sangat kompleks. Manfaat pentingnya memberikan ASI eksklusif dapat melindungi bayi dari sindrom kematian bayi mendadak atau SIDS (Sudden Infant Death

Syndrome).Namun, menciptakan pemberian ASI sejak hari pertama tidak selalu mudah karena banyak ibu menghadapi masalah dalam melakukannya.Kejadian yang sering terjadi pada hari pertama menyusui adalah sulitnya ASI keluar. Hal ini 
membuat ibu berpikir bahwa bayi mereka tidak akan mendapat cukup ASI sehingga ibu sering mengambil langkah berhenti menyusui dan menggantinya dengan susu formula. Di samping itu, ada juga ibu yang merasa takut dan menghindar menyusui, akibatnya akan terjadi pembendungan dan statis ASI karena akan mengurangi isapan bayi pada payudara, maka jumlah ASI yang dikeluarkan sedikit. Sedangkan di negara berkembang, banyak ibu merasa cemas dan menggunakan jadwal dalam pemberian ASI, sehingga kuantitas ASI yang dihasilkan tidak mencukupi kebutuhan bayi (Nainggolan M, 2009).

Pada tahun 2013 angka cakupan pemberian ASI di Indonesia hanya $42 \%$ angka ini masih dibawah target WHO yang menargetkan cakupan pemberian ASI 50\% .Cakupan pemberian ASI eksklusif di Ibu menyusui harus memperhatikan beberapa hal untuk meningkatkan kualitas dan jumlah volume ASI yang dimilikinya. Ada beberapa saran yang perlu diperhatikan para ibu yang sedang memberikan ASI pada bayi, yaitu: mengkonsumsi sayur-sayuran dan buah-buahan yang dapat meningkatkan volume ASI. Jumlah ASI sedikit bisa diatasi ibu dengan mengkonsumsi sayur katuk, labu siam, kacang panjang dan jantung pisang. Kandungan kimia yang terkandung dalam jantung pisang seperti kalori, protein, lemak, karbohidrat, vitamin A, vitain B1, vitamin $\mathrm{C}$ dan mineral penting seperti fosfor, kalsium dan $\mathrm{Fe}$ (zat besi) akan sangat membantu dalam proses pembuatan ASI(Kappara, 2011)..
Indonesia pada bayi $0-5$ bulan turun dari 62,2\% tahun 2012 menjadi $56,2 \%$ pada tahun 2013, sedangkan di Propinsi Riau pada tahun 2013 hanya mencapai angka 55,9 \% jauh dari yang di target kan oleh kementrian kesehatan yang menargetkan pemberian ASI eksklusif sebesar $80 \%$.

Berdasarkan data dari Dinas Kesehatan Provinsi Riau, bahwa cakupan pemberian ASI eksklusif Tahun 2014mencapai 49,21\% atau 3.214 bayi hal ini menggambarkan bahwa pemberian ASI Eksklusif di Provinsi Riau menurun dibandingkan tahun 2013 yaitu 51,6\% (Sutrisno, 2014).

Berdasarkan data yang diperoleh dari Dinkes Kampar (2015) jumlah cakupan ASI eksklusif terendrah adalah desa Ranah wilayah kerja Puskesmas Kampar hanya 2,29\% dari 87 bayi yang berusia 0-6 bulan data periode Januari-Juni 2015.

Sayur-sayuran tersebut terbukti mampu meningkatkan volume air susu ibu. Selain sayur-sayur tersebut, buah-buahan yang mengandung banyak air akan membantu ibu menghasilkan ASI yang berlimpah, seperti melon, semangka, pear, jantung pisand dan banyak lagi buahbuahan lain yang sangat baik dikonsumsi ibu menyusui (Kappara, 2011).

Jantung pisang mengandung laktagogum. Laktagogum memiliki potensi dalam menstimulus hormon oksitoksin dan prolaktin seperti alkaloid, polifenol, steroid, palfonoid dan substansi lainnya yang paling efektif dalam meningkatkan dan memperlancar produksi ASI

Hasil penelitian yang dilakukan oleh Wahyuni pada tahun 2011 dengan judul "pengaruh pemberian 
jantung pisang dengan kelancaran produksi ASI di Desa Berangin Kabupaten Jember" bahwa hasil penelitian ini menunjukkan adanya pengaruh pemberian jantung pisang terhadap produksi ASI.dengan hasil $\mathrm{P}=0,003$.

Berdasarkan hasil studi pendahuluan yang peneliti lakukan di Desa Kuapan kepada 10 ibu menyusui. 6 orang ibu $(60 \%)$ diantaranya mengatakan ASI mereka sedikit karena produksi ASI tidak lancar, sehingga bayi terus menangis dan ibu menghentikan pemberian ASI Eksklusif. 4 orang ibu (40\%) ibu mengatakan ASI mereka banyak karena produksi ASI lancar, sehingga bayi tidak menangis dan ibu tidak menghentikan pemberian ASI Eksklusif.

Berdasarkan latar masalah dan fenomena yang terjadi diatas, maka peneliti termotivasi untuk melakukan penelitian tentang "pengaruh konsumsi rebusan jantung pisang terhadap peningkatanekskresi ASI pada ibu menyusui di Ranah wilayah kerja Puskesmas Kampartahun 2016

\section{B. Rumusan Masalah}

Rumusan masalah "Apakah ada pengaruh konsumsi rebusan jantung pisang terhadap peningkatanekskresi ASI pada ibu menyusui di Ranah wilayah kerja Puskesmas Kampartahun 2016?"

\section{Tujuan penelitian}

1. Tujuan umum : untuk mengetahuipengaruh konsumsi rebusan jantung pisang terhadap peningkatanekskresi ASI pada ibu menyusui di Wilayah kerja Puskesmas Tambangtahun 2016

2. Tujuan khusus : a. Untuk mengetahui produksi ASI responden sebelum diberikan konsumsi rebusan jantung pisang.

b. Untuk mengetahui produksi ASI responden setelah diberikan konsumsi rebusan jantung pisang.

c. Untuk mengetahui apakah rebusan jantung pisang berpengaruh terhadap peningkatan ekskresi ASI pada ibu menyusui di Wilayah kerja Puskesmas Tambangtahun 2016

\section{Manfaat Penelitian}

Penelitian ini diharapkan bermanfaat secara praktis bagi semua pihak yang terkait adalah sebagai berikut :

1. Aspek teoritis (Keilmuan)

Penelitian ini diharapkan dapat memberikan suatu masukan untuk teori dan menambah hasil imformasi ilmiah dalam menanggulangi permasalahan tentang kelancaran ASI.Hasil penelitian ini dapat digunakan untuk menyusun hipotesis baru dalam merancang penelitian selanjutnya.

2. Aspek praktis (Guna laksana)

Hasil dari penelitian ini diharapkan dapat memberikan kebijakan dalam memperbarui dan meningkatkan pengetahuan, kesiagaan masyarakat dan tenaga kesehatan untuk menanggulangi permasalahan tentang kelancaran ASI.

\section{METODOLOGI}

A. Jenis penelitian ini adalah quasi eksperimen (eksperimen semu) dengan rancangan non-equivalent pretest-posttest. Intervensi yang 
digunakan dalam penelitian ini adalah mengkonsumsi jantung pisang $2 \mathrm{x}$ sehari pada pagi dan sore hari selama 7 hari. Metode nonequivalent pretest-psttest ini digunakan untuk melihat pengaruh konsumsi jantung pisang terhadap peningkatan produksi ASI Pada Ibu Menyusui <40 hari Di Desa Ranah Wilayah Kerja Puskesmas Kampar yang berjumlah 20 orang. Pengambilan sampel dengan tehnik purposive sampling.

Data yang dikumpulkan dalam penelitian ini adalah data kuantitatif yaitu data kelancaran ASI Ibu Menyusui sebelum dan sesudah mengkonsumsi Jantung Pisang.

\section{HASIL PENELITIAN}

Penelitian ini dilakukan pada tanggal 05-15 September tahun 2016 di

\section{A. Analilsa Univariat}

Berdasarkanhasil penelitian dapat diketahui bahwa sebagian besar responden berada pada rentang umur 26-35 tahun yaitu berjumlah 9 orang 60\%), sebagian responden

\section{TerataProduksi ASI Sebelun} Wilayah Kerja Puskesmas Kampartahun 2016

\begin{tabular}{lrrrrr}
\hline & Variabel & Mean & Min-Max & SD & CI 95\% \\
\hline $\begin{array}{l}\text { Produksi } \\
\text { sebelum } \\
\text { rebusan } \\
\text { pisang }\end{array}$ & $\begin{array}{r}\text { konsumsi } \\
\text { jantung }\end{array}$ & $406 \mathrm{cc}$ & $250-550 \mathrm{cc}$ & 79,881 & 362,43 \\
& & & & & \\
\end{tabular}

\section{Sumber: Hasil Penelitian}

Berdasarkan tabel 4.1 hasil penelitian diperoleh bahwa rerata ekskresi ASI sebelum konsumsi

rebusan jantung pisang adalah $406 \mathrm{cc}$ dengan standar deviasi 362,43

Desa Ranah Wilayah Kerja Puskesmas Kampar tahun 2016 dengan jumlah sampel sebanyak20 orang. Hasil penelitian dapat dilihat pada analisa univariat dan bivariat berikut ini :

berpendidikan SMA yaitu sebanyak 7 orang $(46,7 \%)$ dan sebagian besar responden bekerja sebagai IRT yaitu sebanyak 8 orang $(53,3 \%)$

Tabel 4.2 RerataProduksi ASI SesudahPemberian Jantung Pisang di Desa Ranah Wilayah Kerja Puskesmas Kampartahun 2016

\begin{tabular}{rcccc}
\hline Variabel & Mean & Min-Max & SD & CI 95\% \\
\hline Produksi ASI sesudah & $743 \mathrm{cc}$ & $600-900 \mathrm{cc}$ & 82,086 & 697,88 \\
\hline
\end{tabular}




$\begin{array}{lr}\begin{array}{l}\text { konsumsi } \\ \text { rebusan } \\ \text { pisang }\end{array} & \text { konsumsi } \\ & \text { jantung }\end{array}$

Sumber: Hasil Penelitian

Berdasarkan tabel 4.2 diperoleh

adalah 743 cc dengan standar deviasi bahwa rerata ekskresi ASI sesudah 82,086 konsumsi rebusan jantung pisang

\section{B. Analisa Bivariat}

Tabel 4.3 Pengaruh Rebusan Jantung Pisang Terhadap Ekskresi ASI Sebelum dan Sesudah Konsumsi Jantung Pisang di Desa Ranah Wilayah Kerja Puskesmas Kampartahun 2016

\begin{tabular}{lccccc}
\hline Variabel & Mean & $\begin{array}{c}\text { Selisih } \\
\text { Mean }\end{array}$ & SD & CI 95\% & P value \\
\hline
\end{tabular}

EkskresiASI

$\begin{array}{llllll}\text { Sebelum konsumsi rebusan } & 406 \mathrm{cc} & -336,667 & 79,881 & -363,280 & 0,001\end{array}$ jantung pisang

Sesudah konsumsi rebusan $743 \mathrm{cc}$ 82,086 jantung pisang

\section{Sumber: Hasil Penelitian}

Berdasarkan tabel 4.3terlihat bahwa perbedaan antara sebelum konsumsi rebusan jantung pisang dan sesudah konsumsi rebusan jantung pisang adalah -336,667 cc dengan Hasil uji statistik didapatkan nilai $\mathrm{p}$ value 0,001, maka dapat disimpulkan ada pengaruh konsumsi jantung pisang terhadap ekskresi ASI pada ibu menyusui di Desa Ranah Wilayah Kerja Puskesmas Kampar tahun 2016

\section{PEMBAHASAN}

\section{Pengaruh Konsumsi Rebusan}

Jantung Pisang terhadap Ekskresi ASI pada Ibu Menyusui di Desa Ranah wilayah kerja Puskesmas Kampar tahun 2016.

Berdasarkan hasil penelitian tentang pengaruh konsumsi jantung pisang terhadap ekskresi ASI pada ibu menyusui di Desa Ranah wilayah kerja Puskesmas Kampar dapat diperoleh hasil bahwa sebagian besar responden berada pada rentang umur
26-35 tahun yaitu berjumlah 9 orang $60 \%$ ), sebagian responden berpendidikan SMA yaitu sebanyak 7 orang $(46,7 \%)$ dan sebagian besar responden bekerja sebagai IRT yaitu sebanyak 8 orang $(53,3 \%)$.

Berdasarkan hasil penelitian dari 20 responden diperoleh bahwa bahwa rerata ekskresi ASI sebelum konsumsi rebusan jantung pisang adalah 406 cc dengan standar deviasi 362,43 dan rerata ekskresi ASI sesudah konsumsi rebusan jantung pisang adalah $743 \mathrm{cc}$ dengan standar deviasi 82,086. Hasil uji statistik didapatkan nilai $p$ value 0,001 , maka dapat disimpulkan ada pengaruh konsumsi rebusan jantung pisang terhadap ekskresi ASI pada ibu menyusui di Desa Ranah Wilayah Kerja Puskesmas Kampar tahun 2016

Murtiana (2011) mengatakan peningkatan produksi ASI juga dirangsang oleh hormon oksitosin. Peningkatan hormon oksitosin 
dipengaruhi oleh polifenol yang ada pada jantung pisang yang akan membuat ASI mengalir lebih deras dibandingkan dengan sebelum mengkonsumsi jantung pisang. Oksitosin merupakan hormon yang berperan untuk mendorong sekresi air susu (milk let down).

Jantung pisangyang mengandung laktagogum memiliki potensi dalam menstimulasi hormon oksitoksin dan prolaktin seperti alkaloid, polifenol, steroid, flavonoid dan substansi lainnya paling efektif dalam meningkatkan dan memperlancar produksi ASI. Reflek prolaktin secara hormonal untuk memproduksi ASI, waktu bayi menghisap puting payudara ibu, terjadi rangsangan neorohormonal pada puting susu dan areola ibu. Rangsangan ini diteruskan ke hipofisis melalui nervos vagus, kemudian ke lobus anterior. Dari lobus ini akan mengeluarkan hormon prolaktin, masuk ke peredaran darah dan sampai pada kelenjar-kelenjar pembuat ASI. Kelenjar ini akan terangsang untuk menghasilkan ASI (Fahmi, 2011).

Jenis ubi-ubian yang berwarna ungu ini sangat baik untuk dijadikan makanan untuk memperbanyak ASI seperti ubi jalar. Di dalam ubi jalar berwarna kuning ini mengandung laktagogum yang bisa meningkatkan ASI dan juga mengandung zat besi serta karotenoid yang bisa membantu memperlancar ASI. Yang lebih bagusnya lagi dalam ubi jalar mengandung kalsium yang tinggi (Lestaari, 2014).

Peran oksitosin pada kelenjar susu adalah mendorong kontraksi sel-sel miopitel yang mengelilingi alveolus dari kelenjar susu, sehingga dengan berkontraksinya sel-sel miopitel isi dari alveolus akan terdorong keluar menuju saluran susu, sehingga alveolus menjadi kosong dan memacu untuk sintesis air susu berikutnya (Rohima, 2011).

Saadatullah

(2009),

menyatakan bahwa jantung pisang yang berkhasiat terhadap peningkatan sekresi air susu (laktogogum) mempunyai kandung bahan aktif yang bekerja seperti Prolactin Releasing Hormon (PRH), mengandung bahan aktif senyawa steroid, mengandung bahan aktif yang berkhasiat seperti prolaktin dan mengandung bahan aktif yang berkhasiat seperti oksitosin.

Menurut asumsi peneliti kurangnya ekskresi ASI pada ibu menyusui karena ibu beranggapan ASI tidak akan cukup untuk memenuhi kebutuhan bayi, sehingga ibu merasa takut dalam memberikan ASI kepada bayi dan puting susu yang tidak menonjol yang mengakibatkan ibu tidak memberikan ASI kepada bayinya. Teknik yang salah dalam menyusi bayi juga dapat mempegaruhi ibu tidak memberikan ASI pada bayinya. Jantung pisang mengandung laktagogum yang memiliki beberapa senyawa yang dapat meningkatkan produksi dan kualitas ASI. Peningkatan produksi ASI dipengaruhi oleh adanya polifenol dan steroid yang mempengaruhi reflek prolaktin untuk merangsang alveoli yang bekerja aktif dalam pembentukan ASI.

Hasil penelitian ini sesuai dengan penelitian Nurliana (2013) dengan judul pengaruh jantung pisang batu terhadap peningkatan produksi ASI pada Ibu Menyusui di Wilayah Puskesmas Srikuncoro Kecamatan Pondok Kelapa Bengkulu 
Tengah. Darihasil penelitian ini diperoleh bahwa intensitas rata-rata frekuensi ASI sebelum konsumsi jantung pisang batu adalah 5,7 kali. Setelah mengkonsumsi jantung pisang batu, mengalami peningkatan menjadi 9,75 kali. Perbedaan nilai rata-rata peningkatan Produksi ASI adalah 5,458 dengan sig 0,000. Karena < 0,05, kesimpulan $\mathrm{Ha}$ diterima yang berarti ada pengaruh konsumsi jantung batu terhadap peningkatan Pengaruh Konsumsi Jantung Pisang Batu terhadap Peningkatan Produksi ASI.

\section{DAFTAR PUSTAKA}

Astutik. (2014).Payudara dan Laktasi. Jakarta; Salemba Medika.

Astawan. (2007).Jantung Pisang Memperlancar ASI. Jakarta; Nuha Medika

Depkes RI. (2009). Pemberian ASI Eksklusif pada ibu menyusui. dari http//pemberian-ASI-pada-ibumenyusui. Diperoleh tanggal 10 Mei 2016

Dinas Kesehatan Kabupaten Bengkulu. (2012). Jumlah cakupan ASI di Dinas Kesehatan Bengkulu

Setiawan. (2009). Panduan Terlengkap Pasca Melahirkan. Surakarta; Cinta.

Dinas Kesehatan, Kab. Kampar. (2014). Cakupan Pemberian ASI Perpuskesmas.

Hidayat. (2007). Metode Penelitian Keperawatan dan Teknik Analisis Data. Jakarta; Salemba Medika.
Haris. (2011). Cakupan pemberian ASI di Indonesia. Dari http//panduanASI-di-Indonesia. Diperoleh tanggal 13 Mei 2016.

Juwono. (2004). Masalah pemberian ASI. Yogyakarta; Pustakabarupress.

Kappara. (2014). Sehat dengan herbal warisan nenek moyang penumpas segala penyakit. Penerbit; Media Ilmu Abadi

Khotimah. (2013). Cara konsumsi jantung pisang dalam memperlancar ASI. Dari http//cara-konsumsi-jantungpisang-memperlancar-asi. Diperoleh tanggal 12 Mei 2016

Melvyn. (2006). Khasiat Jantung Pisang. Bogor; In Media.

Mrenstein. (2001). Pisang Batu memperlancar produksi ASI pada Ibu Menyusui. Yogyakarta: Pustaka Press

Murtiana. (2010). Makanan tambahan untuk kelancaran ASI pada ibu. Dari http//makanan-tambahanASI. Diperoleh tanggal $18 \mathrm{Mei}$ 2016.

Notoatmodjo. (2010).Metodologi Penelitian Kesehatan. Jakarta; Rineka Cipta

Nursalam. (2013). Metodologi Penelitian Ilmu Keperawatan. Edisi 3. Jakarta; Salemba Medika. 
Nainggolan. (2009). Khasiat dan Manfaat pemberian ASI pada bayi. Jakarta; Agro Medika Pustaka.

WHO. (2012). Asi eksklusif. Dari httphttp://digilib.unimus.ac.idDipe roleh tanggal 10 Maret 2016.

Wahyuni. (2013). Kandungan jantung pisang dalam melancarkan produksi ASI. Dari $\mathrm{http} / /$.Kandungan-jantung-pisangdalam-melancarkan-produksi-

ASI. Diperoleh tanggal 12 Juni 2016 